\title{
The Effect of Work Experience and OHS on Tax Office Staff's Performance
}

\author{
Agus Bandiyono ${ }^{1}$, Renzo Ilham Ryandhi ${ }^{2}$, and Yuni Betti Mariani ${ }^{3}$ \\ ${ }^{1,2,3}$ Politeknik Keuangan Negara STAN \\ Email Address: \\ agusbandiyono@pknstan.ac.id
}

\begin{abstract}
This research aims to see the effect of work experience and occupational health and safety (OHS) on the staff's performance at the Tax Service Office (KPP). In this study, the research took place at KPP Madya Palembang and KPP Minyak dan Gas Bumi. The research method used is quantitative research. The population in this study were all staff at KPP Madya Palembang and KPP Minyak dan Gas Bumi totaling 70 people. Sampling using Slovin with a standard error of $10 \%$. The data collection techniques used were interview and questionnaire techniques. The data were processed using multiple linear regression analysis models with the help of the SPSS program. From the research results, it is known that work experience and occupational safety and health have a positive and significant effect on the staff's performance of the tax service office.
\end{abstract}

Keywords: management, taxation, occupational health and safety; performance; work experience.

\begin{abstract}
Abstrak: Penelitian ini bertujuan untuk mengetahui pengaruh pengalaman kerja dan keselamatan dan kesehatan kerja (K3) terhadap kinerja pelaksana pada Kantor Pelayanan Pajak. Dalam penelitian ini mengambil lokasi pada KPP Pelayanan Pajak Madya Palembang dan Kantor Pelayanan Pajak Minyak dan Gas Bumi. Metode penelitian yang digunakan adalah penelitian kuantitatif. Populasi dalam penelitian ini adalah seluruh pegawai dengan jabatan pelaksana di Kantor Pelayanan Pajak Madya Palembang dan Kantor Pelayanan Pajak Minyak dan Gas Bumi yang berjumlah 70 orang. Pengambilan sampel menggunakan slovin dengan standar kesalahan $10 \%$. Teknik pengumpulan data dalam penelitian ini dengan menggunakan teknik wawancara dan kuesioner. Data diolah menggunakan model analisis regresi linier berganda dengan bantuan program SPSS. Dari hasil penelitian diketahui bahwa pengalaman kerja dan keselamatan dan kesehatan kerja memiliki pengaruh yang positif dan signifikan terhadap kinerja pelaksana kantor pelayanan pajak.
\end{abstract}

Kata Kunci: manajemen, perpajakan, kesehatan dan keselamatan kerja, kinerja, pengalaman kerja. 


\section{INTRODUCTION}

The organization is a group of people and resources that are deliberately formed to achieve certain goals. In the process of achieving organizational goals, some elements continue to undergo changes and updates that can affect the existence of the organization such as the work processes of the organization. Work processes should be measured so that their implementation can be evaluated and updated in line with developments in science, knowledge, and technology. The emergence of an effective and efficient work process as a support for organizational success is certainly supported by many factors such as the quality of work of human resources and the conditions of the organization's environment, both internal and external. Staff and the physical environment are representative elements that make up the internal environment of the organization (Griffin, 2014). Therefore, we cannot deny that human resources are the central and strategic factors of all organizational activities (Larasati, 2018).

Quality human resources are expected by every organization so that they can survive and adapt in an increasingly changing era (Hafni and Salim, 2018). Efforts to manage and develop staff value are a must for every organization so that staff always give their best contribution by continuously improving the quality of their performance. Therefore, human resource management is needed as a tool in organizations that aims to optimize the productivity of each worker (Larasati, 2018). One way to measure the success of human resource management is to measure performance.

Performance is an achievement obtained by a person in carrying out a task in a certain period based on predetermined standards or targets (Elphiana et al., 2017). KPP Madya Palembang and KPP Minyak dan Gas Bumi are vertical units at the Directorate General of Taxes (DGT) which aim to optimize state revenues. It takes a readiness to implement an optimal KPP's duties and functions to achieve the goals (Bandiyono \& Rahmawati, 2018). Many tools can be used to assess the optimal implementation of KPP's duties and functions, one of which is to evaluate the performance of staff (Bandiyono and Rahmawati, 2018). In measuring the performance of its staff, the DGT organization has a special procedure, namely by filling in the realization of the Main Performance Indicators (IKU) and Staff's Performance Targets (SKP) compared to the performance targets that have been determined at the beginning of the year in a web-based application called e-performance of the Ministry of Finance and SIKKA. The performance appraisal achievement report is used as material for evaluating organizational performance by the leadership. (Hafni and Salim, 2018) explained that the better the staff's performance, the faster the organizational goals will be realized.

Staff's performance can be influenced by several factors, one of which is work experience. (Husain, 2018) argues that work experience can be found in staff who have the knowledge to deal with various types of problems according to their capacity because they have more working hours. Experienced staff are always better and easier to carry out work to maintain work productivity than non-experienced or fresh graduates (Panambunan et al., 2017). This is in line with the research of (Panambunan et al., 2017) which proves that staff's performance is significantly influenced by the work experience of the staff.

Experienced job applicants should be considered more by organizations than less experienced job applicants (Husain, 2018). The recruitment of staff of the Directorate General of Taxes is carried out selectively in three ways, namely the selection of CPNS 
Ministry of Finance based on PMK 129/2015, selection in PKN STAN based on PMK 184/2018, and acceptance of open positions based on PermenPANRB 15/2019. So, based on the selection process, it can be concluded that the age range of staff with staff positions who work at the Tax Office, as a DGT vertical unit, is between 19-58 years. Staff's age affects the work experience of staff, this is supported by the opinion of (Almutahar et al., 2015) stated that younger workers are generally unable to do work if compared to older workers. This is due to several factors, one of which is work experience.

One of the other objectives of the DGT organizations is to provide quality public service. This objective is part of the KPP's duties and functions. Based on the Law on Public Services as stated in (Bandiyono, 2018), administrative services and public goods and services are the scopes of public services. This includes operational activities carried out by KPP. Service quality can be assessed from consumer responses based on the comparison between the quality of service obtained and the expected (Komala et al., 2005). When the quality opposite to what was expected, public dissatisfaction will emerge and of course, this is one of the factors that cause the small number of taxpayer compliance (WP) (Mahardika, 2015). The quality of public services provided by the Directorate General of Taxes organization may be influenced by the work experience of tax officer. This is in line with research by (Siahaan and Sianturi, 2017) which states that the work experience of tax staff has a positive and significant effect on the quality of tax services. In addition, work experience also affects the implementation of other routine and administrative tasks. Therefore, the age range can cause differences in the performance of each staff in the Directorate General of Taxes due to various work experiences.

On the other hand, during the COVID-19 pandemic, the government has determined that incident is a national disaster following Keppres 12/2020. Based on the International Labor Organization (ILO) report in 2020, states that the working world is one of the sectors that are directly affected by the COVID-19. As of this writing, data at the Ministry of Health (DetikNews, 2020) states that positive cases of COVID-19 in Indonesia have reached 493,308 cases. To minimize the risk of this pandemic, especially to minimize the risk of transmission in the world of work, the Government through the Ministry of Health has established provisions related to the implementation of health protocols as part of Occupational Health and Safety (OHS) which is mandatory for every office. This provision is regulated in the Decree of the Minister of Health Number HK.02.01/Menkes/216 of 2020.

(ILO, 2020) states that a higher risk of COVID-19 transmission is found in workers who provide basic services so that special risk control is required for these workers. And one of the staff roles is to provide services to taxpayers at the Integrated Service Place (TPT). In this situation, staff will interact directly with taxpayers so that the activity certainly has a high risk of spreading the virus. One of company concern for the work health and safety of its staff is by making rules on OHS that every worker must comply with (Gayatri, 2015). The existence of OHS assurance in the work environment can have a good influence on staff morale (Elphiana et al., 2017). However, a proper understanding of OHS by staff and organizational management is sometimes still minimal, such as an understanding of the proper OHS implementation rules and the impact if the organization does not apply OHS (Yuliandi and Ahman, 2019). One of the triggers for work accidents is unsafe working conditions (Thaha, 2016). In addition, a lack of good understanding of OHS by workers and companies can also be a trigger for work accidents (Yuliandi and Ahman, 2019). 
In the era of globalization, OHS is an important thing. The risk of OHS in the work environment has increased during the COVID-19 pandemic so that it requires the commitment of all parties, both government and private, from all lines in the organization to improve OHS (Frans, 2015). There is government coordination to ensure the implementation of OHS in the work environment of the Directorate General of Taxes in the pandemic era, one of which is issuing a regulation to staff containing an appeal to comply with the provisions of the health protocol in preventing the spread of COVID-19 in the work environment as well as regulating the work system with the implementation of Work From Home. That is the importance of implementing to protect from dangers and diseases in work environment so that staff feel safe and comfortable in carrying out their duties. Gayatri (2015) in her journal states that staff health has a positive influence on work productivity which also affects the success of the company's business. Therefore, it can be believed that in achieving organizational goals there is a significant role of OHS management (Suartha and Sintaasih, 2015).

Based on the description above, it can be understood that the importance of work experience and OHS (especially in the pandemic era) in influencing the staff's performance of the Directorate General of Taxes. Improving staff's performance will certainly have a positive impact on the achievement of the Directorate General of Taxes goals, especially in providing superior services to taxpayers as stakeholders so that it is expected to create tax compliance in the implementation of tax services (Bandiyono and Augustine, 2019). This performance improvement can be started with an increase in the quality of the staff's performance which is the lowest level in the organizational structure of the Directorate General of Taxes. Therefore, this is the basis for the author to conduct a research entitled "The Effect of Work Experience and OHS on Tax Office Staff's Performance". This study hopes that it can become a reference in human resource management and OHS management.

\section{THEORITICAL REVIEW}

Human Resource Management (HRM). Melayu SP. Hasibuan in Siregar (2017) argues that HRM is an art in regulating workers in their relationships and their role in realizing organizational goals effectively and efficiently. In the KPP organizational structure, HR management is carried out by the General and Internal Compliance Subdivision which carries out duties, one of which is the management of staff's performance.

Work Experience. (Likdanawati, 2018) states that work experience is the knowledge that staff get while working in an organization. The more experienced a staff, the more knowledge he will have to complete his duties and responsibilities, especially in dealing with various kinds of cases and problems that often occur in the work environment.

Occupational Health and Safety (OHS). (Kani et al., 2013), stated that OHS is a science that discusses efforts to prevent the risk of accidents and diseases from work operations, both knowledge and its application. The definition related to work safety is described by (Mangkunegara, 2000) (Busyairi et al., 2014), namely conditions in the work environment that can provide a sense of security to staff from the risk of damage or accidents at work. One of the efforts to maintain workplace safety for staff at KPP is by establishing a legal basis and SOP for each type of work to protect the staff from mistakes and workplace 
accidents that can harm them and the organization. (Firmanzah et al., 2017) states that occupational health is a healthy condition, both physically and spiritually, which encourages workers to have work productivity. The health facilities programs is important to maintain the mental and physical health of its staff, including staff, so that they can improve their performance by working more productively.

Performance. (Muttaqijn et al., 2018) describes the performance as the realization of the work results of staff in carrying out their duties following the division of work and their respective responsibilities which are assessed both in terms of quality and quantity of work. The responsibility given to each staff in the KPP has been planned and determined at the beginning of the period including the quality and quantity so that the performance results can be known at the end of the period in an staff's performance appraisal.

Hypothesis of the Relationship between Work Experience and Staff's performance. (Husain, 2018) conducted a study entitled "The Effect of Work Experience on Staff's performance (PT Bank Negara Indonesia Tbk Bumi Serpong Damai Branch Office)". The results of this study indicate that work experience has a significant positive effect on performance. In this context, the researcher formulated the first hypothesis in this study in the form of:

H1: Work experience has a positive effect on the staff's performance at KPP Madya Palembang and KPP Minyak dan Gas Bumi.

Hypothesis on the Relationship between Occupational Health and Safety and Staff's performance. (Gayatri, 2015) conducted a study entitled "The Relationship between Occupational Health and Safety (OHS) and Staff's performance at PT. UOB Indonesia Bengkulu Branch ". The result of this study is that OHS has a significant positive effect on performance. In this context, the researchers formulated the second hypothesis in this study in the form of:

H2: Occupational Health and Safety has a positive effect on staff's performance at KPP Madya Palembang and KPP Minyak dan Gas Bumi.

Thought Framework. (Hafni and Salim, 2018) describe the framework as a chart that describes the theoretical linkages used with the variables in the study. For this research, the researcher describes the frame of mind as follows: 


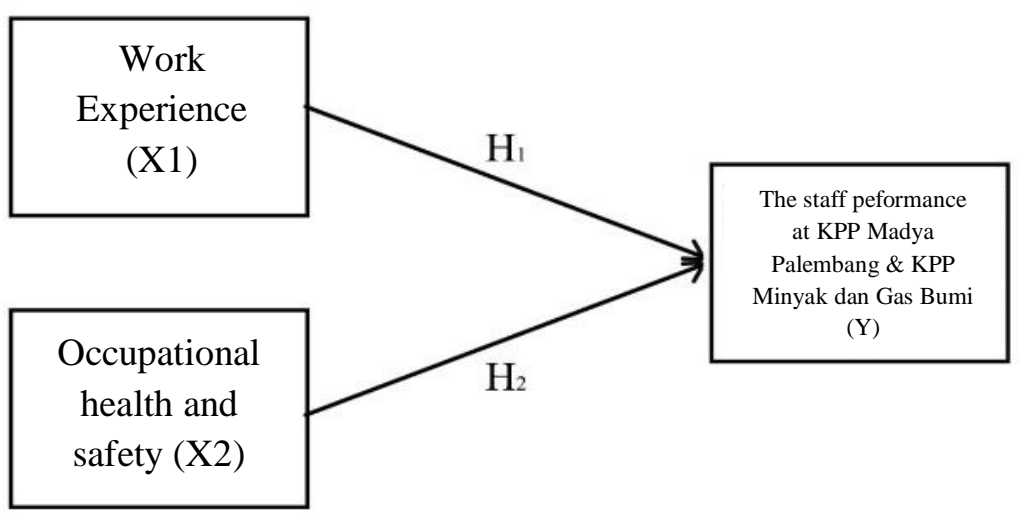

Figure 1. Thought Framework

Source: Processed data, 2020

\section{METHODS}

Location and Time of Research. In this study, the authors made KPP Madya Palembang and KPP Minyak dan Gas Bumi as the research objects. The reason the authors chose the two KPPs is that in the organizational structure of the Directorate General of Taxes, both are vertical units that have to carry out supervision, service, and counseling to taxpayers. Several things are also into consideration by the author in choosing the object of this research, among others: (1) The differences in the criteria for which taxpayers are administered. KPP Madya Palembang administers large regional taxpayers while KPP Minyak dan Gas Bumi administers taxpayers who operate in the oil and gas mining sector and geothermal exploitation. (2) The differences in ethnicity and local culture at the KPP location. KPP Madya Palembang, located in South Sumatra, certainly has a different ethnicity and culture from KPP Minyak dan Gas Bumi, both in terms of taxpayers and staff. (3) The difference in levels of spreads of the COVID-19 virus. KPP Madya Palembang is included in the orange zone while KPP Minyak and Gas Bumi which is located in Kalibata, South Jakarta is in the red zone, which means that more new cases are found than in the orange zone.

The research was conducted from December 1, 2020, to January 31, 2021.

Research Method. Method used was a quantitative approach. This approach is carried out in testing predetermined hypotheses using quantitative data analysis tools on the population represented by a particular sample (Husain, 2018). The variables used consisted of two independent variables and one dependent variable, including work experience, OHS, and staff's performance respectively.

Population and Sample. The population is the set of objects and/or subjects that are determined to be studied and concluded in research with certain characteristics and qualities (Husain, 2018). The population in this research is the staff at KPP Madya Palembang and KPP Minyak dan Gas Bumi totaling 70 people. 
The sample is part of the population that is the focus of attention. Samples were taken using the Slovin formula, which is the formula for determining the minimum number of samples from a limited population. The equation of the Slovin formula is:

$$
n=\frac{N}{1+N e^{2}}
$$

$\mathrm{n}$ is the minimum number of samples, $\mathrm{N}$ is the number of limited populations, and $\mathrm{e}$ is the standard of error (error rate) and can be determined by the researcher. In this case, the researcher uses a standard of error of $10 \%$ or $e=0.1$ with the population totaling 70 staff. Obtained:

$$
n=\frac{70}{1+70(0,1)^{2}}=41.176
$$

or the minimum number of samples is 42 staff (rounded up).

Data Collection Techniques. To obtain data, the authors conducted a series of data collection activities at KPP Madya Palembang and KPP Minyak dan Gas Bumi from December 2020 to January 2021.

Literature Research Methods. The author collects theoretical basis from several literature consisting of books, journals, news, articles, previous research, lecturer teaching materials, and other written documents related to research.

Field Research Methods. The author collects data and information from respondents or informants directly. In the field research method, the writer distributes questionnaires and conducts interviews. The questionnaire is a data collection technique by giving several questions to respondents to be answered both in form and in sheets (Husain, 2018). Closeended questions are used on questionnaires.

The interview is a data collection technique utilizing direct and active interaction between researchers and research subjects to obtain good and accurate data (Rosaliza, 2015). Interviews in this research were conducted with 4 informants with the following criteria: (1) Are staff of KPP Madya Palembang or KPP Minyak dan Gas Bumi. (2) Are staff who are engaged in one of the following fields:Head of Service Section; Integrated Service Places (TPT) staff; Personnel staff. 
Based on these criteria, the research sources obtained were as follows:

Table 1. Informant List

\begin{tabular}{l|l|l|l|l}
\hline No & \multicolumn{1}{|c|}{ Name } & \multicolumn{1}{|c}{ Position / Field of } & \multicolumn{1}{|c}{ Origin Office } & \multicolumn{1}{c}{ Code } \\
\hline 1 & Evy Rahayu Eko Boediarti & $\begin{array}{l}\text { Head of the Services } \\
\text { Section }\end{array}$ & $\begin{array}{l}\text { KPP Minyak dan } \\
\text { Gas Bumi }\end{array}$ & Informant 1 \\
\hline 2 & Diah Pusparini & TPT staff & $\begin{array}{l}\text { KPP Minyak dan } \\
\text { Gas Bumi }\end{array}$ & Informant 2 \\
\hline 3 & Yopie Dwi Deswandi & TPT staff & $\begin{array}{l}\text { KPP Madya } \\
\text { Palembang }\end{array}$ & Informant 3 \\
\hline 4 & Ainun Na'imi & Personnel staff & $\begin{array}{l}\text { KPP Madya } \\
\text { Palembang }\end{array}$ & Informant 4 \\
\hline
\end{tabular}

Source: Processed Data, 2020

Data Collection Instruments. Instrument in data collection is described by (Hafni and Salim, 2018) as a tool to produce appropriate qualitative data through measurement in the form of scale. In this study, the measurement of each variable used in the questionnaire is a likert scale. The likert scale is used to assess the opinions, perceptions, and attitudes of a person and/or group of people regarding social phenomena. In each question, there are answer choices Strongly Agree (SS), Agree (S), Neutral (N), Disagree (TS), and Strongly Disagree (STS).

Data Analysis Methods. (Gani and Amalia, 2015) argue that the statistical data analysis method is strongly influenced by the truth and accuracy of the data obtained. To test the truth and accuracy of the data, the researcher conducted several statistical tests, including: (1) The validity test shows the suitability of the questions on the questionnaire in collecting research data. (2) The normality test shows the level of distribution of research results data.

Furthermore, to analyze the relationship between the independent variables, namely Work Experience (X1) and OHS (X2) with the dependent variable, namely Staff's performance (Y), the researchers conducted several statistical tests as follows: (1) The linearity test shows the degree of a linear relationship between the independent variable and the dependent variable. (2) The correlation test shows the level of closeness between the independent variable and the dependent variable. (3) The simple regression test shows the level of influence of the independent variable and the dependent variable. (4) Hypothesis testing aims to test whether the hypothesis can be accepted or rejected. 


\section{RESULT}

Table 2. Normality Test Result (One-Sample Kolmogorov-Smirnov Test)

\begin{tabular}{|c|c|c|}
\hline \multicolumn{2}{|l|}{$\overline{\mathbf{N}}$} & Unstandardized Residual \\
\hline Normal Parameters ${ }^{\mathrm{a}, \mathrm{b}}$ & & 43 \\
\hline \multirow{2}{*}{$\begin{array}{l}\text { Normal Parameters }{ }^{\mathrm{a}, \mathrm{b}} \\
\text { Most Extreme Differences }\end{array}$} & Mean & .0000000 \\
\hline & Std. Deviation & 3.36989552 \\
\hline \multirow{3}{*}{$\begin{array}{l}\text { Most Extreme Differences } \\
\text { Test Statistic }\end{array}$} & Absolute & .103 \\
\hline & Positive & .080 \\
\hline & Negative & -.103 \\
\hline \multicolumn{2}{|l|}{ Asymp. Sig. (2-tailed) } & .103 \\
\hline \multirow{2}{*}{\multicolumn{2}{|c|}{$\begin{array}{l}\text { Source: Processed data with SPSS, } 2021 \\
\text { a. Test distribution is Normal. } \\
\text { b. Calculated from data. } \\
\text { c. Lilliefors Significance Correction. }\end{array}$}} & $.200^{\mathrm{c}, \mathrm{d}}$ \\
\hline & & \\
\hline
\end{tabular}

Based on the output results in Table 2, it was found that the normality test resulted in a significance level of 0.200 (greater than $5 \%$ or 0.05 ). So it is concluded that the data in this study are normally distributed so that the assumption of normality from the multiple regression model is fulfilled.

Linearity Test

Table 3. Linearity Test Result (ANOVA) On Variable X1

\begin{tabular}{|c|c|c|c|c|c|c|c|}
\hline & & & $\begin{array}{c}\text { Sum of } \\
\text { Squares }\end{array}$ & Df & $\begin{array}{c}\text { Mean } \\
\text { Square }\end{array}$ & $\mathbf{F}$ & Sig. \\
\hline \multirow{5}{*}{$\begin{array}{l}\text { TOTALY * } \\
\text { TotalX1 }\end{array}$} & \multirow{3}{*}{$\begin{array}{l}\text { Between } \\
\text { Groups }\end{array}$} & (Combined) & 1220.057 & 18 & 67.781 & 3.838 & .001 \\
\hline & & Linearity & 938.321 & 1 & 938.321 & 53.131 & .000 \\
\hline & & $\begin{array}{l}\text { Deviation } \\
\text { from Linearity }\end{array}$ & 281.736 & 17 & 16.573 & .938 & .545 \\
\hline & \multicolumn{2}{|c|}{ Within Groups } & 423.850 & 24 & 17.660 & & \\
\hline & \multicolumn{2}{|c|}{ Total } & 1643.907 & 42 & & & \\
\hline
\end{tabular}

Source: Processed data with SPSS, 2021

Based on the results of the linearity test on variables $\mathrm{X} 1$ and $\mathrm{Y}$ in Table 3, resulting in a deviation from linearity Sig. 0.545 (greater than $5 \%$ or 0.05 ). So it can be concluded that Work Experience and Staff's performance have a significant linear relationship. 
Table 4. Linearity Test Result (ANOVA) On Variable X2

\begin{tabular}{llc|c|c}
\hline & & TOTAL XI & TOTAL X2 & TOTAL Y \\
\hline \multirow{2}{*}{ TOTAL X1 } & Pearson Correlation & 1 & $.583^{* *}$ & $.756^{* *}$ \\
\cline { 2 - 5 } & Sig. (2-tailed) & & .000 & .000 \\
\cline { 2 - 5 } & $\mathrm{N}$ & 43 & 43 & 43 \\
\hline \multirow{2}{*}{ TOTAL X2 } & Pearson Correlation & $.583^{* *}$ & 1 & $.743^{* *}$ \\
\cline { 2 - 5 } & Sig. (2-tailed) & .000 & & .000 \\
\cline { 2 - 5 } & $\mathrm{N}$ & 43 & 43 & 43 \\
\hline \multirow{2}{*}{ TOTAL Y } & Pearson Correlation & $.756^{* *}$ & $.743^{* *}$ & 1 \\
\cline { 2 - 5 } & Sig. (2-tailed) & .000 & .000 & 43 \\
\cline { 2 - 5 } & $\mathrm{N}$ & 43 & 43 & 43 \\
\hline
\end{tabular}

**. Correlation is significant at the 0.01 level (2-tailed).

Source: Processed data with SPSS, 2021

Based on the results of the linearity test on variables $\mathrm{X} 2$ and $\mathrm{Y}$ in Table 4, it produces a deviation from the linearity of Sig. amounting to 0.514 (greater than $5 \%$ or 0.05 ). So it can be concluded that OHS and Staff's performance have a significant linear relationship.

Table 5. Correlation Test Result

\begin{tabular}{|c|c|c|c|c|c|c|c|}
\hline & & & $\begin{array}{c}\text { Sum of } \\
\text { Squares }\end{array}$ & Df & $\begin{array}{c}\text { Mean } \\
\text { Square }\end{array}$ & $\mathbf{F}$ & Sig. \\
\hline \multirow{5}{*}{$\begin{array}{l}\text { TOTALY * } \\
\text { TOTALX2 }\end{array}$} & \multirow{3}{*}{$\begin{array}{l}\text { Between } \\
\text { Groups }\end{array}$} & (Combined) & 1284.907 & 21 & 61.186 & 3.579 & .003 \\
\hline & & Linearity & 908.585 & 1 & 908.585 & 53.148 & .000 \\
\hline & & $\begin{array}{l}\text { Deviation } \\
\text { from Linearity }\end{array}$ & 376.322 & 20 & 18.816 & 1.101 & .514 \\
\hline & \multicolumn{2}{|c|}{ Within Groups } & 359.000 & 21 & 17.095 & & \\
\hline & \multicolumn{2}{|l|}{ Total } & 1643.907 & 42 & & & \\
\hline
\end{tabular}

Correlation Test. Based on the results of the correlation test in Table 5, the Sig. value is obtained between $\mathrm{X} 1$ and $\mathrm{Y}$ is $0.00<0.05$. So it can be concluded that there is a significant correlation between the Work Experience and Staff's performance. Furthermore, the Sig. value is known between $\mathrm{X} 2$ and $\mathrm{Y}$ is $0.00<0.05$. So it can be concluded that between the OHS and Staff Perfomance there is also a significant correlation.

Table 6. Simple Linear Regression Test Result (Coefficientsa)

\begin{tabular}{|c|c|c|c|c|c|c|}
\hline \multirow[b]{2}{*}{ Model } & & \multicolumn{2}{|c|}{ Unstandardized Coefficients } & \multirow{2}{*}{$\begin{array}{c}\text { Standardized } \\
\text { Coefficients } \\
\text { Beta } \\
\end{array}$} & \multirow[b]{2}{*}{$\mathbf{T}$} & \multirow[b]{2}{*}{ Sig. } \\
\hline & & B & Std. Error & & & \\
\hline \multirow[t]{3}{*}{1} & (Constant) & 2.376 & 4.509 & & -.527 & .601 \\
\hline & TOTAL X1 & .617 & .133 & .488 & 4.655 & .000 \\
\hline & TOTAL X2 & .343 & .078 & .459 & 4.379 & .000 \\
\hline
\end{tabular}

a. Dependent Variable: TOTAL Y

Source: Processed data with SPSS, 2021

Regression test shows the level of influence of the independent variable (X) on a dependent variable (Y). The regression equation from the output in Table 6 is described as follows: 


$$
\begin{gathered}
\mathrm{Y}=\boldsymbol{\alpha}+\boldsymbol{\beta 1 X 1}+\boldsymbol{\beta 2 X 2} \\
\text { Or } \\
\mathrm{Y}=\mathbf{2 , 3 7 6}+\mathbf{0 , 6 1 7 X 1}+\mathbf{0 , 3 4 3 X 2}
\end{gathered}
$$

Explanation of the equation:

The constant is 2.376 , meaning that if $\mathrm{X} 1$ and $\mathrm{X} 2$ are assumed to be 0 or there are no Work Experience and OHS variables, then the Staff's performance (Y) will have a value constant of 2.376 .

The variable $\mathrm{X} 1$ has a regression coefficient value of 0.617 . In this case, if the other independent variables have a fixed value and the X1 variable increases by 1 unit, then the $\mathrm{Y}$ variable increases by 0.617 so that the increase in work experience, the staff's performance will also increases.

The variable $\mathrm{X} 2$ has a regression coefficient value of 0.343 . In this case, if the other independent variables have a fixed value and the $\mathrm{X} 2$ variable increases by 1 unit, then the $Y$ variable increases by 0.343 so that the increases in OHS, the staff's performance will also increase.

Hypothesis Test (T). The criteria used in the Hypothesis Test include:

If $\mathrm{t}$ count $>\mathrm{t}$ table with sig $\leq(\alpha=0.05)$ then $\mathrm{H} 0$ is rejected. The conclusion that can be drawn is that the independent variable (X1 or X2) partially affects the dependent variable (Y);

If $\mathrm{t}$ count $<\mathrm{t}$ table with $\operatorname{sig} \leq(\alpha=0.05)$ then $\mathrm{H} 0$ is accepted. The conclusion that can be drawn is that the independent variable (X1 or X2) partially does not affect the dependent variable (Y).

With a significance level of $5 \%$ or 0.05 , the $t$ table obtained from the $t$ statistical table is

\begin{tabular}{|c|c|c|c|c|c|c|}
\hline \multirow{2}{*}{\multicolumn{2}{|c|}{ Model }} & \multicolumn{2}{|c|}{$\begin{array}{l}\text { Unstandardized } \\
\text { Coefficients }\end{array}$} & \multirow{2}{*}{$\begin{array}{c}\text { Standardized } \\
\text { Coefficients } \\
\text { Beta } \\
\end{array}$} & \multirow[b]{2}{*}{$\mathbf{t}$} & \multirow[b]{2}{*}{ Sig. } \\
\hline & & B & Std. Error & & & \\
\hline \multirow[t]{2}{*}{1} & (Constant) & .736 & 5.349 & & .138 & .891 \\
\hline & TotalX1 & .955 & .129 & .756 & 7.384 & .000 \\
\hline
\end{tabular}
1.68288

Table 7. The Effect of Variable X1 On Variable Y (Coefficients ${ }^{\mathrm{a}}$ )

a. Dependent Variable: TOTAL Y

Source: Processed data with SPSS, 2021

Based on the output in Table 7, the t count for variable X1 is 7.384 with a significance value of 0.00 so that it can be formulated :

a. The value of $t$ count $>t$ table: $7.384>1.68288$;

b. The significance $0.00<0.05$.

This means that $\mathrm{H} 0$ is rejected, so it can be concluded that the work experience partially has a significant effect on staff's performance. 
Table 8. The Effect of Variable X2 On Variable Y (Coefficients ${ }^{\mathrm{a}}$ )

\begin{tabular}{|c|c|c|c|c|c|c|}
\hline \multirow[b]{2}{*}{ Model } & & \multicolumn{2}{|c|}{$\begin{array}{l}\text { Unstandardized } \\
\text { Coefficients }\end{array}$} & \multirow{2}{*}{$\begin{array}{c}\text { Standardized } \\
\text { Coefficients } \\
\text { Beta } \\
\end{array}$} & \multirow[b]{2}{*}{$\mathbf{t}$} & \multirow[b]{2}{*}{ Sig. } \\
\hline & & B & Std. Error & & & \\
\hline \multirow[t]{2}{*}{1} & (Constant) & 12.416 & 3.923 & & 3.165 & .003 \\
\hline & TOTALX2 & .556 & .078 & .743 & 7.118 & .000 \\
\hline
\end{tabular}

Based on Table 8, it can be seen that the $\mathrm{t}$ value for the variable $\mathrm{X} 2$ is 7,118 and is significant at 0.00 so that it can be formulated :

a. The value of $t$ count $>t$ table: $7,118>1.68288$;

b. The significant $0.00<0.05$.

This means that $\mathrm{HO}$ is rejected, so it can be concluded that OHS partially has a significant effect on staff's performance.

\section{DISCUSSION}

The Effect of Work Experience (X1) on Staff's performance (Y). The results of questionnaire data processing are based on Table 7, indicating that with a significance of 0.05 it is concluded that $\mathrm{X} 1$ owned by the staff partially has a significant effect on Y. Furthermore, based on Table 6: Regression Test Results shows that the coefficient value of $\mathrm{X} 1$ is 0.617 , or for every increase of 1 the value of $\mathrm{X} 1$ will add to the $\mathrm{Y}$ value of 0.617 .

The two test results indicate that work experience has a positive influence on the staff's performance so that H1: Work experience has a positive effect on the staff's performance at KPP Madya Palembang and KPP Minyak dan Gas Bumi is accepted. This is also supported based on the research of Husain (2018) which states that the work experience of staff has a positive and significant effect on the staff's performance.

The results of this study are reinforced by the following interview results:

Experienced staff are more fluent at work. "Work experience greatly affects the fluency in working. Based on (my) experience, DGT has a lot of work fields, and there are frequent transfers (in personnel), so work experience is very necessary." (Informant 1)

"Work experience is very influential, right? Usually people who are senior with enough experience, they have some kind of instinct or personal way of completing the jobs. As for fluency, I think it is very influential (in my opinion) between the period of work and the fluency in working. " (Informant 3)

Experienced staff have better efficiency. "I think there is a relation between the experienced staff and the staff who are not (less experienced). Usually, the new staff, (their) working is in halting, and groping about it. How a job could be done longer than the experienced staff. Usually the experienced staff are more efficient at work. " (Informant 3)

"Experienced staff already know the rhythm of their work. They've master it the SOPs) and unneed to look at the SOPs, they've understand the business process. As we discussed earlier, the work done is more efficient and effective. Less mistakes that could happened. "(Informant 4) 
Effect of OHS (X2) on Staff's performance (Y). The results of the questionnaire data processing are based on Table 8 , indicating that with a significance of 0.05 , it is concluded that X2 partially has a significant effect on variable Y. Furthermore, based on Table 6: Regression Test Results shows that the coefficient value of X2 is 0.343 , or for every increase of 1 the value of $\mathrm{X} 2$ will add to the $\mathrm{Y}$ value of 0.343 .

The two test results indicate that OHS has a positive influence on the staff's performance so that H2: Occupational Health and Safety has a positive effect on staff's performance at KPP Madya Palembang and KPP Minyak dan Gas Bumi is accepted. This is also supported based on research by Gayatri (2015) which states that good OHS management has a positive and significant effect on staff's performance at the office.

The results of this study are reinforced by the following interview results:

The existence of OHS facilities affects the staff productivity.

"If the safety and health of the work are not qualifed, let's say there is something less assuring, the performance will be impacted ... for example, when my safety while working is compromised, such it's a pandemic right now, at the office (while pandemic) makes me unwilling to meet people, that's one. That means when health and safety feel threatened, the works became reluctantly, by feeling a threat to their safety. "(Informant 1).

"A staff who is experiencing minor health problems in the office such that, with the existence of a health facility, they could be handled immediately and in the end, the performance can not be compromised. (in other case) because of lack conditions such as health facilities do not meet (minimum requirement), so the work (by staff) ends up being protracted, eventually it becomes an influence as well. In the end, staff also cannot carry out their activities according to their prime conditions. "(Informant 2).

"Even if staff have to go to the hospital, it likely takes a long time, or when staff have to leave the office, we need to get the permission first. So by the various facilities provided should be a very supportive (factor) to increace office productivity" (Informant 3).

\section{CONCLUSIONS}

Based on the research that has been carried out, there are several conclusions: (1) The work experience has a positive and significant effect on the staff's performance at KPP Madya Palembang and KPP Minyak dan Gas Bumi. The differences in work experience that the staff had could significantly affect the level of performance of the staff at KPP Madya Palembang and KPP Minyak and Gas Bumi. The work experience of the staff in particular could affect the fluency and efficiency of completing work and the quality of work results. (2) Good OHS management has a significant positive effect on the staff's performance at KPP Madya Palembang and KPP Minyak dan Gas Bumi so that differences in OHS management in an office could have a significant effect on the level of staff's performance at KPP Madya Palembang and KPP Minyak dan Gas Bumi. The existence of OHS, in particular, affects the productivity of the staff in working.

Managerial Implications. Based on the research that has been carried out there are several managerial implications: (1) Staff as one of the spearheads of the Directorate General of Taxes' service is expected to provide their best performance. The difference in work experience that each staff had could be managed (in such a way as) to allow a transfer of 
knowledge between experienced staff and less experienced staff, so that the working period limitation could be exceeded to provide the best performance. Transfer of knowledge could be done by sharing about how a task completion done effectively and efficiently. For example, how to provide quality services to taxpayers so that they could give satisfaction feedback and minimize errors that might impact the organization, such as reducing its credibility to financial losses. (2) Occupational Health and Safety (OHS) facilities are expected to receive special attention for each tax service office so the productivity of the staff could always be maintained. In addition, better OHS management could be started by paying attention and maintainance for the air circulation in the office space to make it smoother. (3) The results of the research should be able to provide new insights both for researchers when they return to work in their respective work units and for readers.

Suggestion. Based on the research that has been carried out, the suggestions for the implementation of further research are: (1) This research is carried out with the use of a limited population, sample, and object, so for further research, it is expected to be able to determine the wider population, sample, and object so that there is no bias in the analysis of the research data; (2) This research is limited to work experience and OHS variables. It is hoped that in further research, other variables or factors can be used that can affect the performance of the staff; (3) Future research is expected to be able to formulate interview guidelines with questions that are not too specific so that the interview can run and develop following the responses of the informants.

\section{REFERENCES}

Almutahar, F. F., Wardhani, N., dan Rafie. (2015). Pengaruh Usia, Pengalaman Kerja, Disiplin Kerja, dan Motivasi Kerja Terhadap Produktivitas Pekerja [The Influence of Age, Work Experience, Work Discipline and Work Motivation on Worker Productivity]. Jurnal Mahasiswa Teknik Sipil Universitas Tanjungpura, 1(1), 1-11.

Elphiana, E. G., Yuliansyah M. Diah, dan M. Kosasih Zen. (2017) Pengaruh Keselamatan Dan Kesehatan Kerja Terhadap Kinerja Karyawan PT. Pertamina EP Asset 2 Prabumulih. Jurnal Ilmiah Manajemen Bisnis dan Terapan (Jembatan) 2 (2017).

Frans, A. (2015). Pengaruh kesehatan dan keselamatan kerja (K3), dan insentif terhadap motivasi serta kinerja karyawan pada bagian produksi. Masyarakat, Kebudayaan Dan Politik, 28(4), 219. https://doi.org/10.20473/mkp.v28i42015.219-226.

Gani, I., dan Amalia, S. (2015). Alat Analisis Data: Aplikasi Statistik untuk Penelitian Bidang Ekonomi dan Sosial. Penerbit Andi.

Gayatri, I. A. E. M. (2015). Hubungan Keselamatan Dan Kesehatan Kerja (K3) Dengan Kinerja Karyawan Pada Pt. Uob Indonesia Cabang Bengkulu. EKOMBIS REVIEW: Jurnal Ilmiah Ekonomi Dan Bisnis, 3(2), 185-196. https://doi.org/10.37676/ekombis.v3i2.145.

Griffin, Ricky W. (2004). Manajemen Edisi Ke-7. Jakarta: Erlangga. (First published by Houghton Mifflin Company, Boston, Massachussets, United States of America, Copyright (C) 2002 by Houhgton Mifflin Company. All Rights reserved).

Hafni, L., dan Salim, A. (2018). Pengaruh Keselamatan Kerja, Kesehatan, dan Pengalaman Kerja terhadap Kinerja Karyawan pada PT. Pelayaran Santan Prima Bahari Pekanbaru. Procuratio: Jurnal Ilmiah Manajemen, 6(1), 99-110. 
Husain, B. A. (2018). Pengaruh Pengalaman Kerja Terhadap Kinerja Karyawan. Jurnal Disrupsi Bisnis: Jurnal Ilmiah Prodi Manajemen, Fakultas Ekonomi, Universitas Pamulang, 1(2).

International Labour Organization (ILO). Dalam Menghadapi Pandemi: Memastikan Keselamatan dan Kesehatan di Tempat Kerja. Diakses pada 21 November 2020 dari https://www.ilo.org/wcmsp5/groups/public/---asia/---robangkok/---ilojakarta/documents/publication/wcms_742959.pdf.

Komala, K. C., Suhadak, dan NP, M. G. W. E. (2005). Pengaruh Kualitas Pelayanan Perpajakan Terhadap Kepatuhan Wajib Pajak Badan (Studi Pada Kantor Pelayanan Pajak Madya Malang). Perpajakan, 1-9.

Larasati, S. (2018). Manajemen Sumber Daya Manusia. Deepublish.

Mahardika, I. G. N. P. (2015). Pengaruh Kualitas Pelayanan Dan Sikap Wajib Pajak Terhadap Kepatuhan Pelaporan Wajib Pajak Orang Pribadi. Jurnal Jurusan Pendidikan Ekonomi (JJPE), 5(1), 1-12.

Panambunan, O., Tewal, B., dan Trang, I. (2017). Pengalaman Kerja, Pelatihan Kerja, Iklim Organisasi Dan Pengaruhnya Terhadap Kinerja Pegawai Pt. Pln (Persero) Wilayah Suluttenggo. Jurnal EMBA: Jurnal Riset Ekonomi, Manajemen, Bisnis Dan Akuntansi, 5(2), 2183-2192. https://doi.org/10.35794/emba.v5i2.16506.

Rosaliza, M. (2015). Wawancara, Sebuah Interaksi Komunikasi dalam Penelitian Kualitatif. In Jurnal Ilmu Budaya (Vol. 11, Issue 2, p. 9).

Siahaan, M., dan Sianturi, H. (2017). Pengaruh Pengalaman Kerja dan Motivasi Kerja Pegawai Pajak Terhadap Kualitas Pelayanan Pajak. Jurnal Kajian Ilmiah, 17(3), 96104. http://ojs.ubharajaya.ac.id/index.php/kajian-ilmiah/article/view/134.

Suartha, A. C., dan Sintaasih, D. K. (2015). Penerapan Program Keselamatan Dan Kesehatan Kerja Dan Kompensasi: Pengaruhnya Terhadap Kinerja Petugas Kebersihan Dinas Kebersihan Dan Pertamanan Kota Denpasar. E-Jurnal Manajemen Universitas Udayana, 4(9), 251918.

Thaha, Annisa Ilahi. (2017). Gambaran Kecelakaan Kerja, Penyakit Akibat Kerja dan Postur Janggal pada Pekerja Armada Mobil Sampah TANGKASAKI'(Truk Angkutan Sampah Kita) di Kota Makassar Tahun 2016. Diss. Universitas Islam Negeri Alauddin Makassar, 2017.

Yuliandi, C. D., dan Ahman, E. (2019). Penerapan Keselamatan Dan Kesehatan Kerja (K3) Di Lingkungan Kerja Balai Inseminasi Buatan (Bib) Lembang. Penerapan Keselamatan Dan Kesehatan Kerja (K3) Di Lingkungan Kerja Balai Inseminasi Buatan (Bib) Lembang, 18(2), 98-109.

Kementerian Kesehatan RI. (2020). Surat Edaran Menteri Kesehatan Nomor HK.02.01/Menkes/216 tahun 2020 tentang Protokol Pencegahan Penularan Coronavirus Disease (COVID-19) di Tempat Kerja.

Kementerian Keuangan RI. (2015). Peraturan Menteri Keuangan Nomor 129 Tahun 2015 tentang Tata Cara Pelaksanaan Rekrutmen Calon Pegawai Negeri Sipil di Lingkungan Kementerian Keuangan.

Kementerian Keuangan RI. (2018). Peraturan Menteri Keuangan Nomor 184 Tahun 2018 tentang Pemenuhan Kebutuhan Pegawai Negeri Sipil Melalui Penerimaan Mahasiswa Program Diploma Bidang Keuangan Politeknik Keuangan Negara STAN dan Mekanisme Ikatan Dinas Bagi Lulusan Program Diploma Bidang Keuangan Politeknik Keuangan Negara STAN. 
Kementerian Pendayagunaan Aparaut Negara dan Reformasi Birokrasi RI. (2019). Peraturan Menteri Pendayagunaan Aparatur Negara dan Reformasi Birokrasi Nomor 15 Tahun 2019 tentang Pengisian Jabatan Pimpinan Tinggi Secara Terbuka dan Kompetitif di Lingkungan Instansi Pemerintah.

Pemerintah RI. (2020). Keputusan Presiden Nomor 12 Tahun 2020 tentang Penetapan Bencana Nonalam Penyebaran Corona Virus Disease 2019 (COVID-19) sebagai Bencana Nasional.

Direktorat Jenderal Pajak. Tugas dan Fungsi. Diakses pada 21 November 2020 https://www.pajak.go.id/id/tugas-dan-fungsi-0.

DetikNews (21 November 2020). Tambah 4.998, Ini Sebaran Kasus Corona RI pada 21 November 2020. Diakses pada 21 November 2020. https://news.detik.com/berita/d5264402/tambah-4998-ini-sebaran-kasuscorona-ri-pada-21-november-2020. 